\title{
Scoring system based on electrocardiogram features to predict the type of heart failure in patients with chronic heart failure
}

\author{
Hendry Purnasidha Bagaswoto*, Lucia Kris Dinarti, Erika Maharani, \\ Cardiology and Vascular Educational Program, Faculty of Medicine / Dr. Sardjito General \\ Hospital, Universitas Gadjah Mada, Yogyakarta \\ DOI: http://dx.doi.org/10.19106/JMedSci004803201601
}

\begin{abstract}
Heart failure is divided into heart failure with reduced ejection fraction (HFrEF) and heart failure with preserved ejection fraction (HFpEF). Additional studies are required to distinguish between these two types of HF. A previous study showed that HFrEF is less likely when ECG findings are normal. This study aims to create a scoring system based on ECG findings that will predict the type of HF. We performed a cross-sectional study analyzing ECG and echocardiographic data from 110 subjects. HFrEF was defined as an ejection fraction $\leq 40 \%$. Fifty people were diagnosed with HFpEF and 60 people suffered from HFrEF. Multiple logistic regression analysis revealed certain ECG variables that were independent predictors of HFrEF i.e., LAH, QRS duration > 100 ms, RBBB, ST-T segment changes and prolongation of the QT interval. Based on ROC curve analysis, we obtained a score for HFpEF of -1 to +3 , while HFrEF had a score of +4 to +6 with $76 \%$ sensitivity, $96 \%$ specificity, $95 \%$ positive predictive value, an $80 \%$ negative predictive value and an accuracy of $86 \%$. The scoring system derived from this study, including the presence or absence of LAH, QRS duration > $100 \mathrm{~ms}$, RBBB, ST-T segment changes and prolongation of the QT interval can be used to predict the type of HF with satisfactory sensitivity and specificity.
\end{abstract}

\section{ABSTRAK}

Latar belakang: Gagal jantung dapat dibagi ke dalam 2 tipe yakni gagal jantung dengan penurunan ejeksi fraksi dan gagal jantung dengan normal ejeksi fraksi. Penelitian lebih lanjut diperlukan untuk membedakan kedua tipe gagal jantung. Penelitian yang pernah dilakukan sebelumnya menunjukkan bahwa hasil EKG pada penderita gagal jantung dengan penurunan ejeksi fraksi kebanyakan menunjukkan hasil yang normal. Tujuan dari penelitian ini adalah untuk membuat system skoring berdasarkan temuan EKG yang dapat memprediksi tipe gagal jantung. Metode penelitian ini menggunakan desain potong lintang dimana akan dilakukan analisis hasil temuan EKG dan Ekokardiografi dari 110 subjek. Gagal jantung dengan penurunan ejeksi fraksi didefinisikan sebagai nilai EF $\leq 40 \%$. Lima puluh pasien terdiagnosis sebagai gagal jantung dengan ejeksi fraksi normal, dan sisanya 60 pasien menderita gagal jantung dengan penurunan ejeksi fraksi. Regresi logistik multiple menunjukkan beberapa variable EKG yang dapat menjadi penunjuk terjadinya penurunan ejeksi fraksi, yakni LAH, QRS > 100 MS, RBBB, perubahan segmen ST-T dan pemanjangan interval QT. Berdasarkan analisis menggunakan kurva ROC, didapatkan skor untuk ejeksi fraksi normal -1 sampai +3 , sedangkan untuk penurunan ejeksi fraksi +4

Corresponding author: purnasidha_2002@yahoo.com / arsyadhiracarissa@gmail.com 
sampai +6 dengan sensitivitas $76 \%$, spesifisitas $96 \%$, nilai prediksi positif $95 \%$, nilai prediksi negative $80 \%$ dan akurasi $86 \%$. Simpulan skoring system yang didapatkan dari penelitian ini, yang menunjukkan ada atau tidaknya LAH, QRS $>100 \mathrm{~ms}$, RBBB, perubahan segmen ST-T, pemanjangan interval QT dapat digunakan untuk memprediksi tipe gagal jantung kronik dengan nilai sensitivias dan spesifisitas yang memuaskan.

Keywords: chronic heart failure - scoring system - electrocardiogram features - type of heart failure

\section{BACKGROUND}

Heart failure has a high incidence, is one of the major causes of mortality from cardiovascular diseases in the world and is a major health problem in society. ${ }^{1}$ Heart failure is divided into heart failure with reduced ejection fraction (HFrEF) and heart failure with preserved ejection fraction $(\mathrm{HFpEF}){ }^{2}$ In the literature, HFrEF and HFpEF are also referred to as systolic and diastolic heart failure, respectively. Patients with systolic dysfunction can also exhibit diastolic dysfunction, particularly in late stage heart failure. ${ }^{3}$ The mortality from heart failure is inversely related to left ventricular systolic function. Ejection fraction is considered one of the strongest prognosistic factors that influences a poor outcome for heart failure patients. $^{4}$

Echocardiography is considered the gold standard for assessing diastolic or systolic dysfunction in patients with heart failure. However, an expert is required to conduct the examination and not all health facilities provide an echocardiography machine. Thus, a simple device that can measure both systolic and diastolic function can help a physician determine the diagnosis..$^{5}$ Electrocardiogram (ECG) examination is inexpensive tool that is accessible in almost all primary health care setting. A normal or minor change in the ECG is consistent with a low likelihood of left ventricle dysfunction. Conversely, left ventricle systolic dysfunction is usually accompanied by major ECG changes. ${ }^{6}$ The ECG is useful because it can serve as an initial investigative tools that physicians can use to determine the presence of systolic and diastolic dysfunction in patients with chronic heart failure, though it cannot replace echocardiography.

A scoring system is a simple method for diagnosing disease. ${ }^{7}$ Several scoring systems based on ECG findings have been studied to estimate left ventricular function. However, additional studies have suggested that scoring systems have limitations or are less accurate in estimating left ventricular function in patients with coronary heart disease. ${ }^{8,9}$ To our knowledge, there no previous study has evaluated a scoring system based of ECG results to predict $\mathrm{HFpEF}$ or $\mathrm{HFrEF}$ in patients with heart failure.

\section{METHODS}

We used a cross-sectional research design to determine a scoring system based on ECG findings to predict the type of heart failure (HFpEF or HFrEF). The population consisted of patients with chronic heart failure that were hospitalized or seen as outpatients in Dr. Sardjito General Hospital between April and July 2015 and in whom both echocardiography and ECG had been conducted. The inclusion 
criteria were patients with heart failure diagnosed based on ESC (2012) or AHA (2013) guidelines, the presence of sinus rhythm, age $>18$ years and agreement to participate in the study. The exclusion criteria were patients with congenital heart disease, primary valve disease, massive pericardial effusion, patients with acute coronary syndrome, severe pulmonary disease (cor pulmonale, pneumothorax) or who had pacemakers. The independent variable in this study was the ECG findings in patients with chronic heart failure. The dependent variable was chronic heart failure (HFrEF or HFpEF). The confounding variable was patient medications.

Subjects were enrolled in the cardiovascular clinic, the hospital ward, and the echocardiography clinic at Dr. Sardjito General Hospital Subjects who met the inclusion criteria was included in the study and were enrolled consecutively. The collected data included demographic information, clinical examination, ECG and echocardiography results. Demographic data included age, sex and medication history. Clinical data included the NYHA class determination.

Twelve lead ECGs were obtained by a nurse or a cardiology resident with patients in the supine position at a speed of $25 \mathrm{~mm} / \mathrm{s}$. The ECGs were read by 3 expert physicians (who were blinded to the results of the echocardiogram). The ECG report included an evaluation of heart rhythm and rate, heart axis, presence or absence of: chamber enlargement, intraventricular block, and ST-T segment changes, and the duration of the QRS complex, QT and QTc intervals. A wide QRS complex defined as QRS duration $>100 \mathrm{~ms}$. The echocardiogram was supervised by a cardiologist and 2 expert examiners (who were blinded to the ECG result). Echocardiography data included a determination of the ejection fraction (calculated by Simpson's method) and the presence or absence of diastolic dysfunction. Heart failure was divided into HFrEF and HFpEF. The criterion for a diagnosis of HFrEF and HFpEF was an ejection fraction $\leq 40 \%$ and $>40 \%$, respectively. Subjects were divided into two groups: HFrEF group and HFpEF group.

Bivariate analysis was used to analyze the relationship between the ECG results and $\mathrm{HFrEF}$ or HFpEF. Inter-variable bivariate analysis was analyzed with the Chi-square test followed by Fisher's test. Further, variables in the bivariate analysis with a $p<0.25$ were tested using a multivariate analysis, specifically logistic regression with a backward stepwise method. Each variable from the multivariate analysis was scored by using B and SE values (from SPSS statistical analysis program). There were 2 scoring systems based on the probability and cut-off point from the ROC curve. Next, the scoring system was validated in several samples to obtain the diagnostic value. The entire data analysis was statistically conducted using SPSS software. Additional information about the research subjects that was deemed necessary for the study was collected from the medical record or via a direct interview. Sample data collection was non-probability sampling.

The research was conducted after receiving permission from the faculty of medicine at UGM/RSUP Dr. Sardjito Ethical Committee. Informed consent was obtained from the subjects after they received complete information about the trial.

\section{RESULTS}

Data were collected between April and July 2015 from patients seen in the cardiovascular clinic, hospital ward and echocardiography 
clinic at Dr. Sardjito General Hospital. A total of 110 heart failure patients met the inclusion criteria. Sixty patient $(54.5 \%)$ had systolic heart failure (HFrEF ) and 50 patients had diastolic heart failure (HFpEF). There was no significant difference in the average age of patients in the HFpEF and HFrEF group $(59.7 \pm 9.2$ years and $57.9 \pm 10.1$ years, respectively). All of the subjects met NYHA class II or III criteria (TABLE 1).

TABLE 1. Basic subject characteristics based on heart failure type

\begin{tabular}{|c|c|c|c|c|}
\hline Variable & HFpEF $(n=50)$ & HfrEF $(n=60)$ & Total $(\mathrm{n}=110)$ & $p$ \\
\hline Age, year \pm SD & $59.7 \pm 9.2$ & $57.9 \pm 10.1$ & $58.6 \pm 9.9$ & 0.29 \\
\hline Sex & & & & 0.003 \\
\hline Male, n (\%) & $28(56)$ & $49(81.7)$ & $77(70)$ & \\
\hline Female, n (\%) & $22(44)$ & $11(18.3)$ & $33(30)$ & \\
\hline \multicolumn{5}{|l|}{ Risk factor } \\
\hline Hypertension, n (\%) & $46(92)$ & $39(65)$ & $85(77.2)$ & 0.001 \\
\hline DM, n (\%) & $19(38)$ & $13(21.7)$ & $32(29.1)$ & 0.06 \\
\hline Smoker, n (\%) & $11(22)$ & $29(48.3)$ & $40(36.3)$ & 0.004 \\
\hline \multicolumn{5}{|l|}{ Therapy } \\
\hline ACE-I / ARB, n (\%) & $50(100)$ & $60(100)$ & $110(100)$ & 1.000 \\
\hline Diuretic, n (\%) & $37(74)$ & $57(95)$ & $94(85.4)$ & 0.002 \\
\hline Beta Blocker, n (\%) & $21(42)$ & $30(50)$ & $51(46.3)$ & 0.042 \\
\hline CCB, n $(\%)$ & $22(44)$ & $6(10)$ & $28(25.4)$ & $<0.0001$ \\
\hline
\end{tabular}

HFpEF: Heart Failure preserved Ejection Fraction; HFrEF: Heart Failure reduced Ejection Fraction; DM: Diabetes mellitus; ACE-I: Angiotensin Converting Enzyme Inhibitor; ARB: Angiotensin Receptor Blocker; CCB: Calcium Channel Blocker

Patients with HFrEF had a larger left atrial diameter, LAVI, LVMI, LVIDd and E/A ratio compare to patients with HFpEF, while IVSD, DT and TAPSE were lower in patients with HFrEF. Kinetic disturbance in the myocardium was found in all patients with $\mathrm{HFrEF}$ patient and in $30 \%$ of patients with HFpEF. Characteristics of the echocardiograms are shown in TABLE 2. 
Purnasidha, Scoring system based on electrocardiogram features to predict the type of heart failure in patients with chronic heart failure

TABLE 2. Echocardiography basic characteristics based on heart failure type

\begin{tabular}{|c|c|c|c|}
\hline Variable & HFpEF $(n=50)$ & $\operatorname{HFrEF}(\mathrm{n}=60)$ & $p$ \\
\hline LA Diameter, $\mathrm{mm} \pm \mathrm{SD}$ & $34.3 \pm 5.2$ & $41.5 \pm 6.2$ & $<0.0001$ \\
\hline LVIDd, $\mathrm{mm} \pm \mathrm{SD}$ & $49.2 \pm 7.1$ & $64.9 \pm 7.9$ & $<0.0001$ \\
\hline $\mathrm{IVSd}, \mathrm{mm} \pm \mathrm{SD}$ & $12.5 \pm 2.1$ & $10.3 \pm 2.6$ & $<0.0001$ \\
\hline EF Simpson, $\% \pm$ SD & $59.2 . \pm 8.5$ & $29.4 \pm 6.8$ & $<0.0001$ \\
\hline LVMI, g/m2 \pm SD & $133.3 . \pm 40.2$ & $170.3 \pm 46.7$ & $<0.0001$ \\
\hline Septal e' & $5.09 . \pm 1.1$ & $4.3 \pm 1.2$ & $<0.0001$ \\
\hline Lateral e' & $6.21 \pm 1.6$ & $5.6 \pm 2.5$ & 0.146 \\
\hline LAVI, $\mathrm{ml} / \mathrm{m} 2 \pm \mathrm{SD}$ & $34.5 \pm 4.3$ & $47.1 \pm 14.4$ & $<0.0001$ \\
\hline $\mathrm{E} / \mathrm{A}$ ratio & $0.77 \pm 0.2$ & $1.8 \pm 1.2$ & $<0.0001$ \\
\hline $\mathrm{DT}, \mathrm{ms} \pm \mathrm{SD}$ & $234 \pm 53.3$ & $158.4 \pm 52.8$ & $<0.0001$ \\
\hline Diastolic dysfunction & & & 1.000 \\
\hline relaxation, $\mathrm{n}$ & 39 & 16 & \\
\hline pseudonormal, $\mathrm{n}$ & 11 & 15 & \\
\hline restrictive, $\mathrm{n}$ & 0 & 29 & \\
\hline $\mathrm{TAPSE}, \mathrm{mm} \pm \mathrm{SD}$ & $23.2 \pm 3.1$ & $18.1 \pm 4.3$ & $<0.0001$ \\
\hline $\mathrm{RVSP}, \mathrm{mmHg} \pm \mathrm{SD}$ & $6.64 . \pm 9.1$ & $26.8 \pm 22.6$ & $<0.0001$ \\
\hline Myocard Kinetic disturbance & & & $<0.0001$ \\
\hline yes & 15 & 60 & \\
\hline no & 35 & 0 & \\
\hline Heart rate, $\mathrm{x} /$ minute $\pm \mathrm{SD}$ & $71.8 \pm 12.8$ & $81.7 \pm 15$ & 0.135 \\
\hline
\end{tabular}

LA: left atrium; LVIDd: left ventricular internal diameter end diastole; IVSd: Interventricular septal end diastole; EF: ejection fraction; LVMI: left ventricular mass index; LAVI: left atrial volume index; DT: deceleration time; TAPSE: tricuspid annular plane systolic excursion; RVSP: right ventricle systolic pressure

The major ECG abnormalities were a prolonged QT interval (62.7\%), ST-T segment changes $(55.4 \%)$ and prolonged QRS duration (48.2\%). Thirty eight percent of patients with HFpEF had ST-T segment changes and a prolonged QT interval, while a prolonged QT interval, prolonged QRS duration and ST-T segment changes were found in $83.3 \%, 71.7 \%$ and $70 \%$ of patients with HFrEF, respectively. ECG characteristics are shown in TABLE 3. 
TABLE 3. ECG basic characteristics based on heart failure type

\begin{tabular}{lllll}
\hline ECG Parameter & HFpEF $(\mathrm{n}=50)$ & HFrEF $(\mathrm{n}=60)$ & Total $(\mathrm{n}=110)$ & $p$ \\
\hline LAH, $\mathrm{n}(\%)$ & $6(12)$ & $22(36.7)$ & $28(25.5)$ & 0.003 \\
LVH, $\mathrm{n}(\%)$ & $15(30)$ & $33(55)$ & $48(43.6)$ & 0.008 \\
Poor $R$ wave, $\mathrm{n}(\%)$ & $5(10)$ & $30(50)$ & $35(31.8)$ & $<0.0001$ \\
LAD, $\mathrm{n}(\%)$ & $15(30)$ & $27(45)$ & $42(38.2)$ & 0.107 \\
RAD, $\mathrm{n}(\%)$ & -- & $3(5)$ & $3(2.7)$ & 0.249 \\
Q wave, $\mathrm{n}(\%)$ & $9(18)$ & $17(28.3)$ & $26(23.6)$ & 0.204 \\
Wide QRS, $\mathrm{n}(\%)$ & $10(20)$ & $43(71.7)$ & $53(48.2)$ & $<0.0001$ \\
QRS duration, $\mathrm{ms} \pm \mathrm{SD}$ & $97.3 \pm 20.7$ & $124 \pm 30.4$ & & \\
LBBB, $\mathrm{n}(\%)$ & -- & $12(20)$ & $12(10.9)$ & 0.001 \\
RBBB, $\mathrm{n}(\%)$ & $7(14)$ & $3(5)$ & $10(9.1)$ & 0.181 \\
ST-T changes, $\mathrm{n}(\%)$ & $19(38)$ & $42(70)$ & $61(55.4)$ & 0.001 \\
Prolong $Q T, \mathrm{n}(\%)$ & $19(38)$ & $50(83.3)$ & $69(62.7)$ & $<0.0001$ \\
Interval QTc, $\mathrm{ms} \pm \mathrm{SD}$ & $453.2 \pm 42.8$ & $499 \pm 50.9$ & & \\
\hline
\end{tabular}

LAH: left atrial hypertrophy; LVH: left ventricular hypertrophy; LAD: left axis deviation; RAD: right axis deviation; LBBB: left bundle branch block; RBBB: right bundle branch block

Multivariate analysis (TABLE 4) largest to smallest was a wide QRS (OR demonstrated that the ECG variables 12.657), prolonged QT interval (OR 7.401), influencing whether a patient had HFpEF or HFrEF were LAH, a wide QRS complex, RBBB, ST-T changes and a prolonged QT interval. The power of the association from LAH (OR 4.449), ST-T segment changes (OR 4.35) and RBBB (OR 0.109). Thus, the scores from these variables were used to calculate the scoring system (TABLE 5).

TABLE 4. Multivariate analysis of variable ECG with logistic regression to test the possibility of systolic heart failure or $\operatorname{HFrEF}(\mathrm{n}=110) . *$ = statistically significant $\#=\mathrm{n}$.a

\begin{tabular}{lccc}
\hline ECG Parameter & OR & IK 95\% & $p$ \\
\hline LVH & 1.24 & $0.284-5.407$ & 0.774 \\
Poor $R$ wave & 2.004 & $0.423-9.494$ & 0.381 \\
LAD & 0.661 & $0.161-2.708$ & 0.565 \\
RAD & $\#$ & $\#$ & $\#$ \\
Q wave & 3.756 & $0.947-14.891$ & 0.060 \\
LBBB & $\#$ & $\#$ & $\#$ \\
LAH & 4.449 & $1.109-17.848$ & $0.035^{*}$ \\
Wide $Q R S$ & 12.657 & $3.277-48.895$ & $<0.0001^{*}$ \\
RBBB & 0.109 & $0.012-0.986$ & $0.049^{*}$ \\
ST-T changes & 4.35 & $1.277-14.817$ & $0.019^{*}$ \\
Prolong $Q T$ & 7.401 & $2.134-25.672$ & $0.002^{*}$ \\
\hline
\end{tabular}

LAH: left atrial hypertrophy; LVH: left ventricular hypertrophy; LAD: left axis deviation; RAD: right axis deviation; LBBB: left bundle branch block; RBBB: right bundle branch block 
Purnasidha, Scoring system based on electrocardiogram features to predict the type of heart failure in patients with chronic heart failure

TABLE 5. Calculated score for each ECG variable resulting from the multivariate analysis

\begin{tabular}{lccccc}
\hline ECG Parameter & $\mathrm{B}$ & $\mathrm{SE}$ & $\mathrm{B} / \mathrm{SE}$ & {$[\mathrm{B} / \mathrm{SE}] / \mathrm{x}$} & Score \\
\hline LAH & 1.493 & 0.709 & 2.105 & 1.068 & 1 \\
Wide QRS & 2.538 & 0.69 & 3.678 & 1.865 & 2 \\
RBBB & -2.214 & 1.123 & -1.971 & -1 & -1 \\
ST-T changes & 1.47 & 0.625 & 2.352 & 1.192 & 1 \\
Prolong QT & 2.002 & 0.635 & 3.152 & 1.599 & 2 \\
\hline
\end{tabular}

LAH: left atrial hypertrophy; RBBB: right bundle branch block

The first scoring model was based on a subject's probability of having HFrEF. The minimum score was -1 , and the maximum score was +6 (see TABLE 5). A regression tool was used to calculate the probability of each subject having systolic heart failure (see TABLE 6).

The second scoring model was based on a cut-off point derived from the ROC (Receiver Operating Characteristic) curve analysis. The ROC method is based on a calculation between sensitivity and specificity values surrounding various cut-off points represented in the graph. Results of the ROC curve analysis are shown in FIGURE 1.
TABLE 6. Scoring system based on the probability of systolic heart failure (HFrEF)

\begin{tabular}{cc}
\hline Score & Probability $(\%)$ \\
\hline-1 & 0.9 \\
0 & 3.16 \\
1 & 10.4 \\
2 & 29.3 \\
3 & 59.6 \\
4 & 84 \\
5 & 94.9 \\
6 & 98.5 \\
\hline
\end{tabular}

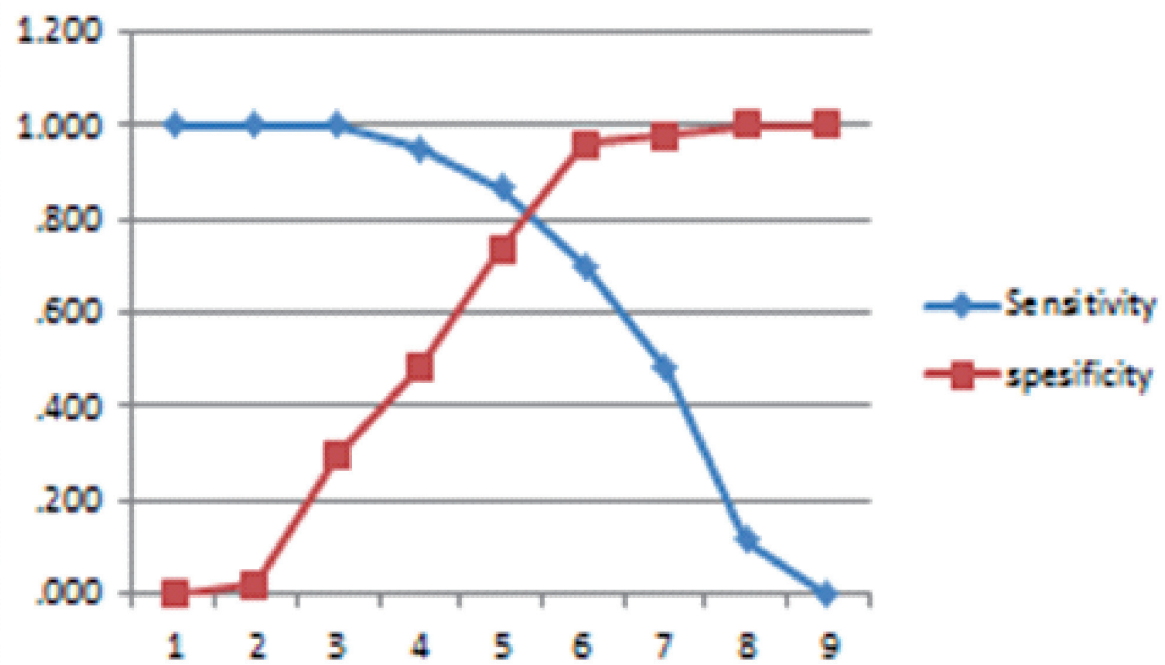

FIGURE 1. This figure shows the sensitivity and specificity based on a cut-off point derived from the ROC (Receiver Operating Characteristic) curve analysis 
From the cut-off analysis in Figure 1, the cut-off value was 4 . A score of +4 to +6 indicated the possibility of systolic heart failure (HFrEF), and a score of -1 to +3 indicated the possibility diastolic heart failure (HFpEF). The scoring system was validated with additional samples to better determine the diagnostic value of the result and demonstrated $76 \%$ sensitivity, $96 \%$ specificity, $95 \%$ positive predictive value, $80 \%$ negative predictive value and an accuracy of $86 \%$ (TABLE 7).

TABLE 7. Validity test based on the scoring system of heart failure patients $(n=50)$

\begin{tabular}{|c|c|c|c|}
\hline & & \multicolumn{2}{|c|}{ ECHO (gold standard) } \\
\hline & & HfrEF $(\mathrm{EF} \leq 40 \%)$ & HfpEF (EF $>40 \%)$ \\
\hline \multirow[t]{2}{*}{ Scoring system } & HfrEF (+4 sd +6) & 19 & 1 \\
\hline & $\operatorname{HfpEF}(-1 \mathrm{sd}+3)$ & 6 & 24 \\
\hline
\end{tabular}

\section{DISCUSSION}

In this study, hypertension was the major risk factor for patients with HFpEF (92\%), while HFrEF was associated with multiple risk factors. This result is in agreement with Paulus and Tschope, ${ }^{10}$ and Tsutsui et al., ${ }^{11}$ who found that hypertension is comorbid in HFpEF, while HFrEF is mostly associated with ischemic heart disease with multiple risk factors such as hypertension, DM or smoking. ${ }^{10,11}$ Patients with HFrEF had evidence of morphological changes such as an increase in the size of the left ventricle accompanied by an increase in end-systolic and end-diastolic volume, reduced wall thickness and increased left ventricular mass. The morphology in patients with HFrEF was opposite to that observed in patients with HFpEF (TABLE 2). ${ }^{12}$ Most of the differences in echocardiography parameters between HFrEF and HFpEF were significant $(p<0.05)$ i.e., LVID size (64.9 \pm 7.9 vs $49.2 \pm 7.1$ $\mathrm{mm})$ and IVSd (12.5 $\pm 2.1 \mathrm{vs} 10.3 \pm 2.6 \mathrm{~mm})$.

ECG changes are usually found in patients with heart failure. This finding is supported by Karaye and Sani who reported ECG abnormalities in $98.2 \%$ of patients with heart failure. Further, the majority of these patients $(65.5 \%)$ had at least 3 types of ECG abnormalities. ${ }^{13}$ If the ECG was normal, the probability that a patient had systolic dysfunction (HFrEF) was small., Multivariate analysis showed that LAH, a wide QRS complex, RBBB, ST-T segment changes and a prolonged QT interval were independent predictors of systolic heart failure (HFrEF) (TABLE 4).

LAH on ECG was found in $25.5 \%$ of patients (28 out of the total number of patients). Of these, $78.5 \%$ ( 22 cases; $p=0.003$ ) were from patients with HFrEF. This result is similar to that reported in a study by Karaye and Sani, ${ }^{13}$ in which LAH was more commonly found in patients with an ejection fraction $<50 \%$ compared to those with an ejection fraction $\geq 50 \%(77.5 \%$ vs $22.4 \% ; p=0.001) .{ }^{13}$ In this study, a prolonged QRS duration $>100$ $\mathrm{ms}$ was predominantly found in patients with HFrEF compare to those with HFpEF $(81.1 \%$ vs $18.9 \%$ ), with values of $124 \pm 30.4$ vs, $97.3 \pm 20.7 \mathrm{~ms}$, respectively. Murkofsky et al. ${ }^{14}$ showed that a prolonged QRS duration $(>0.10$ second) is a very specific, though not a very 
sensitive, indicator of left ventricular systolic function. A QRS duration of $>0.10$ seconds has a high likelihood of being associated with an ejection fraction $<45 \%{ }^{14}$

RBBB was mostly found in patients with HFpEF compared to those with HFrEF (70\% vs 30\%), while LBBB was found in $20 \%$ of patients with HFrEF and in no patients with HFpEF. This result is similar to the findings by Lee et al. ${ }^{15} \mathrm{RBBB}$ is caused by myocardial ischemia, infarction, inflammation (myocarditis), chronic increase in right ventricular pressure (cor pulmonale) and a sudden dilatation of the right ventricle (observed in acute pulmonale secondary to emboli). Less common causes of RBBB include hypertension, cardiomyopathy and congenital heart disease. ${ }^{16} \mathrm{RBBB}$ is also found in subjects without any underlying disease (isolated RBBB). ${ }^{17}$ In our study, the presence of RBBB in patients with HFpEF might have been related to age, coronary artery disease, hypertension or due to isolated RBBB.

ST-T segment changes were evident in 61 patients (55.4\%). Of these, 68.8\% (42 patients) were found in patients with HFrEF and 19 patients with HFpEF. This finding is supports similar findings by Basnet et al., ${ }^{18}$ who reported that ST-T segment changes are a common ECG finding that is present in $48.57 \%$ of patients with left ventricular systolic dysfunction. Nielsen et al., ${ }^{19}$ also found that ECGs with significant Q wave abnormalities, LBBB and ST-T segment changes $(\mathrm{p}<0.012)$ are associated with left ventricle systolic dysfunction. Strain pattern ST-T segment changes have a strong association with a left ventricle internal dimension (LVIDd) $>55$ mm compared to a posterior wall thickness $>12 \mathrm{~mm}$. This observation explains the strong association between strain pattern and ventricular hypertrophy with eccentric vs. concentric remodelling. ${ }^{20}$
A prolonged QTc interval was found in 69 patients $(62.7 \%)$. Of these, $72.4 \%$ (50 patients) were patients with HFrEF. The average QTc interval in patients with HFrEF was also longer than that of patients with HFpEF $(499 \pm 50.9$ vs $453.2 \pm 42.8 \mathrm{~ms}$; $\mathrm{p}=0.000)$. Wilcox et al. ${ }^{21}$ showed that patients with grade II or III diastolic dysfunction have longer QTc intervals compare to patients with non-diastolic or grade I diastolic dysfunction (QTc 461 \pm 34 vs $432 \pm 32 \mathrm{~ms}$; $\mathrm{p}=0.0003$ ). In our study, most of the patients with HFrEF has grade III diastolic dysfunction (restrictive type) $(48.3 \%)$, while $78 \%$ of patients with HFpEF had grade I diastolic dysfunction (relaxation type).

A limitation of our study is variable duration of heart failure therapy for each patient, though it is difficult to determine the impact this would have on our results.

\section{CONCLUSION}

Our study suggests that a scoring system based on ECG findings that include the presence or absence of LAH, a wide QRS duration, RBBB, ST-T segment changes and a prolonged extended QTc interval can be used to predict the type of heart failure (HFpEF and HFrEF) in patients with chronic heart failure. This scoring system has a sensitivity of $76 \%$, a specificity of $96 \%$, a positive predictive value of $95 \%$, a negative predictive value of $80 \%$ and an accuracy of $86 \%$. A score of -1 to +3 suggests the possibility of HFpEF, while a score of +4 to +6 suggests the possibility of HFrEF.

\section{ACKNOWLEDGEMENT}




\section{REFERENCES}

1. Vasan RS and Levy D. Heart failure due to diastolic dysfunction: definition, diagnosis and treatment. In: McMurray JJV and Pfeffer MA, editor. Heart failure updates. United Kongdom: Martin Dunitz, 2003; 1-13.

2. Yancy CW, Jessup M, Bozkurt B, Butler J, Casey DE Jr, Drazner MH, et al. 2013 ACCF/ AHA guideline for the management of heart failure: executive summary: a report of the American College of Cardiology Foundation/ American Heart Association Task Force on practise guidelines. Circulation 2013; 128(16):1810-52.

http://dx.doi.org:10.1161/CIR.0b013e31829e 8707.

3. McMurray JJ, Adamopoulos S, Anker SD, Auricchio A, Bohm M, Dickstein K, et al. ESC Guidelines for the diagnosis and treatment of acute and chronic heart failure 2012: the task force for the diagnosis and treatment of acute and chronic heart failure 2012 of the European Society of Cardiology. Developed in collaboration with the Heart Failure Association (HFA) of the ESC. Eur Heart J 2012; 33(14):1787-847. http://dx.doi. org/10.1093/eurheartj/ehs104.

4. Ponikowski P, Jankowska EA, Banasiak W. Prognosis in Diastolic Heart Failure. In: Smiseth OA and Tendera M, editor. Diastolic Heart Failure. London: Springer-Verlag, 2008; p:213-220.

5. Dickstein K, Filippatos G, McMurray JV, Ponikowski P, Stromberg A, Keren A, et al. ESC Guidelines for the diagnosis and treatment of acute and chronic heart failure 2008: the task force for the diagnosis and treatment of acute and chronic heart failure 2008 of the European Society of Cardiology. developed in collaboration with the heart failure association of the ESC (HFA) and endorsed by the European Society of Intensive
Care Medicine (ESICM). Eur Heart J 2008; 29(19):2388-442. http://dx.doi.org/10.1093/ eurheartj/ehn309.

6. Davie AP, Francis CM, Love MP, Caruana L, Starkey IR, Shaw TR, et al. Value of the electrocardiogram in identifying heart failure due to left ventricular systolic dysfunction. BMJ 1996; 312(7025):222.

7. Dahlan MS. Penelitian prognostik dan sistem skoring. Jatinangor: Penerbit Alqa Prisma Interdelta, 2011; p:49-125.

8. Young SG, Abouantoun S, Savvides M, Madsen EB, Froelicher V. Limitations of electrocardiographic scoring systems for estimation of left ventricular function. J Am Coll Cardiol 1983; 1(6):1479-88.

9. Fioretti P, Brower RW, Lazzeroni E, Simoons ML, Wijns W, Reiber JHC, et al. Limitation of a QRS scoring system to assess left ventricular function and prognosis at hospital discharge after myocardial infarction. $\mathrm{Br}$ Heart J 1985; 53(3):248-52.

10. Paulus WJ, Tschope C. A novel paradigm for heart failure with preserved ejection fraction: comorbidities drive myocardial dysfunction and remodeling through coronary microvascular endothelial inflammation. J Am Coll Cardiol 2013; 62(4):263-71. http:// dx.doi.org/ 10.1016/j.jacc.2013.02.092.

11. Tsutsui H, Tsuchihashi-Makaya M, Kinugawa S. Clinical characteristics and outcomes of heart failure with preserved ejection fraction: lesson from epidemiological studies. J Cardiol 2010; 55(1):13-22. http://dx.doi.org/ 10.1016/j.jjcc.2009.09.003.

12. Chatterjee K, Massie B. Systolic and diastolic heart failure: differences and similarities. $\mathrm{J}$ Card Fail 2007; 13(7):569-76.

13. Karaye KM, Sani MU. Electrocardiographic abnormalities in patients with heart failure. Cardiovasc J Afr 2008; 19(1):22-5.

14. Murkofsky RL, Dangas G, Diamond JA, Mehta D, Schaffer A, Ambrose JA. 
A prolonged QRS duration on surface electrocardiogram is a spesific indicator of left ventricular dysfunction. J Am Coll Cardiol 1998; 32(2):476-82.

15. Lee DS, Gona P, Vasan RS, Larson MG, Benjamin EJ, Wang TJ, et al. Relation of disease pathogenesis and risk factors to heart failure with preserved or reduced ejection fraction: insights from the framingham heart study of the national heart, lung, and blood institute. Circulation 2009; 119(24):3070-7.http://dx.doi.org/ 10.1161/ CIRCULATIONAHA.108.815944.

16. Sauer WH. Overview of right bundle branch block. UpToDate 19.3.

17. Surawicz B, Tavel ME, Knilans TK, Gering LE. Chou's Electrocardiography in Clinical Practice. Philadelphia: Saunders Elsevier, 2008; p: 75-92; 29-43.

18. Basnet BK, Manandhar K, Shrestha R, Thapa M. Electrocardiograph and chest X-Ray in prediction of left ventricular systolic dysfunction. JNMA J Nepal Med Assoc 2009; 48(176):310-3.

19. Nielsen OW, Hansen JF, Hilden J, Larsen CT, Svanegaard J. Risk assessment of left ventricular systolic dysfunction in primary care: cross sectional study evaluating a range of diagnostic tests. BMJ 2000; 320(7229):2204.

20. Okin PM, Devereux RB, Nieminen MS, Oikarinen L, Jern S, Viitasalo $\mathrm{M}$, et al. Relationship of the electrocardiographic strain pattern to left ventricular structure and function in hypertensive patients: the LIFE study. Losartan Intervention For End point. J Am Coll Cardiol 2001; 38(2):514-20.

21. Wilcox JE, Rosenberg J, Vallakati A, Gheorghiade M, Shah SJ. Usefulness of electrocardiographic QT interval to predict left ventricular diastolic dysfunction. Am J Cardiol 2011; 108(12):1760-6. http://dx.doi. org/ 10.1016/j.amjcard.2011.07.050. 